\title{
PRELIMI NARY NOTES
}

PN 41036

\section{Relation of amino acid transport to sodium-ion concentration}

The dependence of amino acid transport on the presence and the distribution of the alkali metals was first noted in $195^{1}{ }^{1}$. In I958 RIGGS, WALKER AND CHRISTENSEN showed that the ability of the Ehrlich cell to accumulate glycine decreased in proportion to the extent that $\mathrm{Na}^{+}$replaces cellular $\mathrm{K}^{+}$(ref. 2). The results of that research (Fig. 6 in ref. 2) effectively dissociated the ability of the cell to concentrate glycine from the distribution of $\mathrm{K}^{+}$, and associated it with the distribution of $\mathrm{Na}^{+}$, although the discussion failed to take note of that evidence in choosing potassium as perhaps the critical cation. Other authors have occasionally disregarded both the alternate hypotheses and the evidence by citing only the tentative preference. Subsequently, KROMPHARDT et al. showed that glycine is principally sensitive to $\mathrm{Na}^{+}$as the external alkali metal ${ }^{3}$, a finding that has been repeatedly confirmed. In the meantime a similar finding for monosaccharide transport by the intestine also called attention to the sodium ion.

Recently VIDAvER has shown that the net direction of a mediated transport for glycine in the pigeon erythrocyte depends strictly on the direction of the $\mathrm{Na}^{+}$ gradient between the exterior and the interior of the cell' ${ }^{4}$. VIDAVER observed further that the rate of glycine uptake increased with the $\mathrm{Na}^{+}$concentration according to

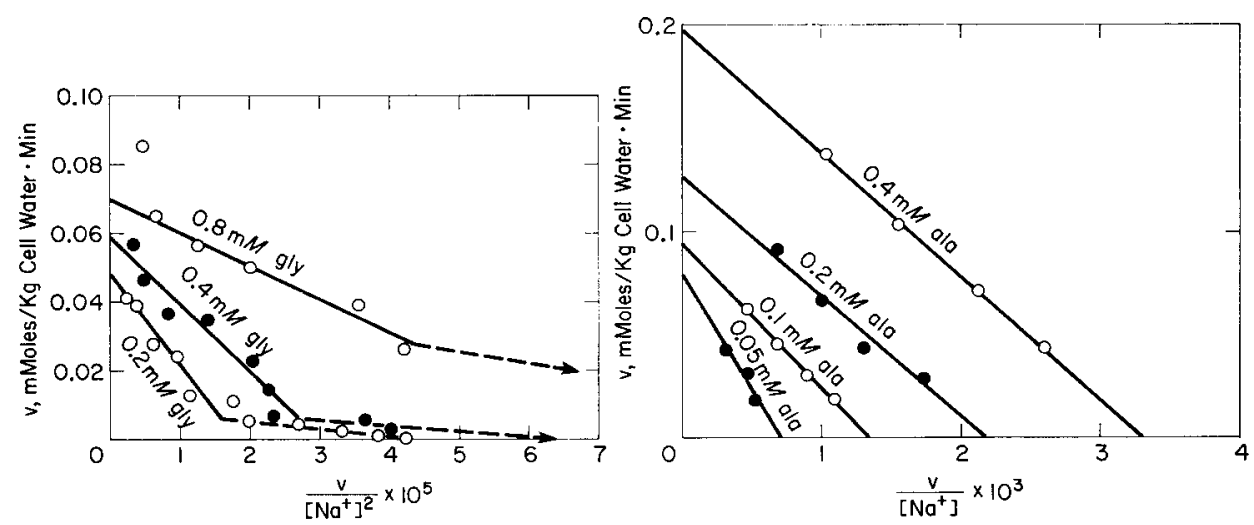

Fig. I. Rate of uptake of glycine (left) and alanine (right) by pigeon erythrocytes at various cxternal $\mathrm{Na}+$ levels. Uptake was measured by incubating at $37^{\circ}$, Io min for $[\mathbf{I}-14 \mathrm{C}]$ glycine, $3 \mathrm{~min}$ for $\mathrm{L}-\left[\mathrm{I}^{14} \mathrm{C}\right]$ alanine, in solutions containing from o to $134 \mathrm{mM} \mathrm{NaCl}, 1.2 \mathrm{mM} \mathrm{CaCl}, 0.6 \mathrm{mM} \mathrm{MgSO}$, $8.0 \mathrm{mM} \mathrm{K}_{2} \mathrm{HPO}_{4}$, 2.0 $\mathrm{mM} \mathrm{KH}_{2} \mathrm{PO}_{4}$, and enough choline chloride to substitute for NaCl. Uptake was terminated by pouring into an equal volume of buffered ice-cold choline chloride, and centrifuging $3 \mathrm{~min}$ at ${ }^{\circ}$. After removing the supernatant solution (the last portion by capillarity into paper strips) the cells were extracted with ro vol. $5 \%$ trichloroacetic acid, and radioactivity determined both in the extract and the external medium by liquid-scintillation counting. The uptake rate observed in the absence of $\mathrm{Na}^{+}$(small except in the case of glycine) has been deducted in all cases. Under the conditions followed the radioactivity can be recovered in the form of the unchanged amino acid. For glycine (left) the Augustinsson plot is linear over a greater range when one introduced $\left[\mathrm{Na}^{+}\right]^{2}$ (as shown) rather than $\left[\mathrm{Na}^{+}\right]$. (Data of EAvenson.) 
the Michaelis-Menten equation, when the second-power rather than first-power of the $\mathrm{Na}^{+}$concentration was introduced as $[S]$ into that equation ${ }^{5}$.

The present communication reports confirmation of the finding of VIDAVER that better correspondence is obtained with the square rather than the first power of $\left[\mathrm{Na}^{+}\right]$ at $\mathrm{Na}^{+}$levels above $20 \mathrm{mM}$, although at lower $\mathrm{Na}^{+}$levels this relationship is no longer followed (Fig. I, left). In contrast, the rate of uptake of L-alanine by a different mediating system in the same cell (Fig. I, right), also the rate of its mediated uptake into the rabbit reticulocyte (Fig. 2), and the rate of the saturable uptake of $\alpha$-aminoisobutyric acid by the Ehrlich cell (Fig. 3, left), all follow the Michaelis-Menten equation if $\mathrm{Na}^{+}$is introduced as its first power. The same result was obtained for

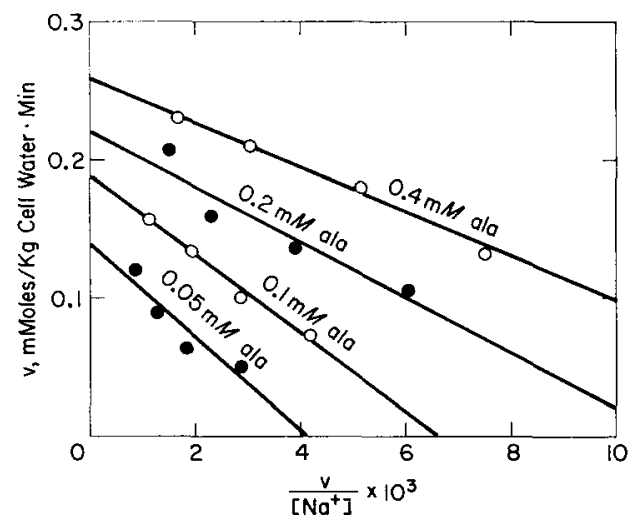

Fig. 2. Rate of alanine uptake by reticulocytes at various levels of $\mathrm{Na}^{+}$. Rabbit red cells (6I $\%$ reticulocytes) were washed twice with $0.154 \mathrm{M}$ choline chloride; then $0.2-\mathrm{ml}$ samples were held $2 \mathrm{~min}$ at $20^{\circ}$ in $5 \mathrm{ml}$ medium containing $\mathrm{I} \mathrm{mM} \mathrm{MgSO}{ }_{4}, \mathrm{I}_{4} \mathrm{mM}$ Tris $-\mathrm{HCl}(\mathrm{pH} 7.6)$, and various levels of $\mathrm{L}$-alanine and $\mathrm{Na}^{+}$as shown, choline chloride being substituted for $\mathrm{NaCl}$ to obtain isoosmolarity. Other conditions as for Fig. I, except uptake was terminated by adding $5 \mathrm{ml}$ of ice-cold o.I54 M KCl, followed by 2 min of centrifugation at $0^{\circ}$. (Data of WhEELER.)
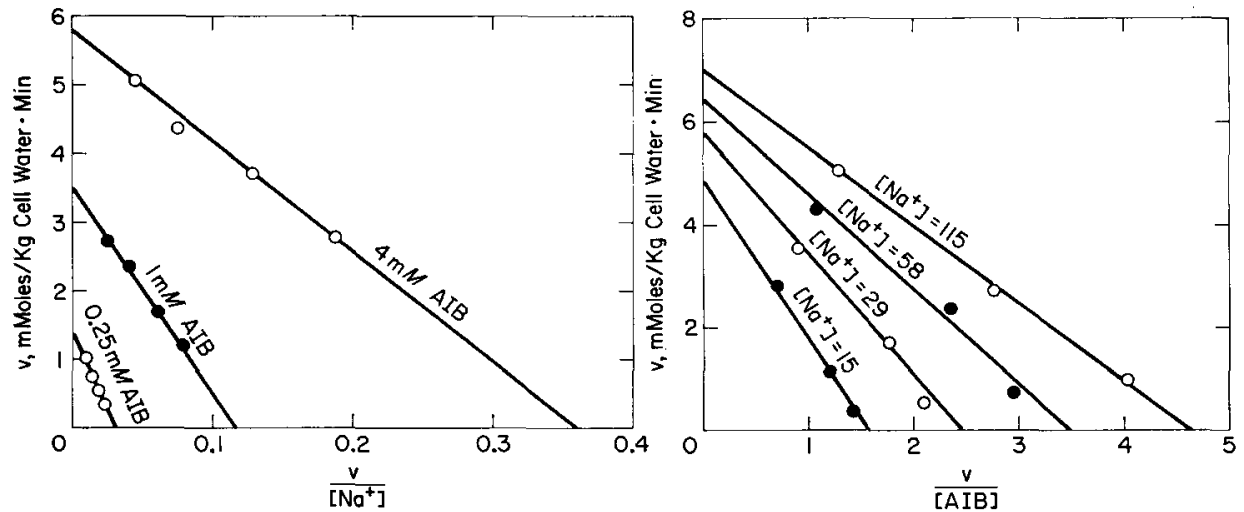

Fig. 3. Uptake rate of $\alpha$-amino $\left[{ }^{-14} \mathrm{C}\right]$ isobutyric acid (AIB) by the Ehrlich ascites tumor cell at various concentrations of $\mathrm{Na}^{+}$. Uptake was measured during $\mathbf{I}$ min at $37^{\circ}$ in Krebs--Ringer bicarbonate medium modified to contain $26 \mathrm{mM} \mathrm{K}^{+}$, various levels of $\mathrm{NaCl}$ as shown, and choline chloride to obtain iso-osmolarity. Other conditions approximately as in Fig. I. Left, correspondence to Michaelis-Menten equation when $\left[\mathrm{Na}^{+}\right]$(rather than $\left[\mathrm{Na}^{+}\right]^{2}$ ) is introduced. Right, same data replotted to show $\mathrm{Na}^{+}$effect on both $V_{\max }$ (shift in intercept on vertical axis) and $K_{m}$ (change in slope) for $\alpha$-aminoisobutyric acid uptake. (Data of INUr; results typical of those obtained with reticulocytes and pigeon erythrocytes.) 
the $\mathrm{Na}^{+}$-sensitive portion of the uptake of L-methionine by the Ehrlich cell. Furthermore, the influence of changing $\mathrm{Na}^{+}$in these several cases is to change $K_{m}$ as well as $V_{\max }$, as is illustrated in Fig. 3, right. That result is in contrast with an observation by Crane, Forstner and EichHol $Z^{6}$ that the effect of changing $\mathrm{Na}^{+}$levels on glucose transport by the hamster small intestine can be described by changes in the $K_{m}$ only, for glucose. Changes in both $K_{m}$ and $V_{\max }$ can be shown a theoretical expectation, however, when $\mathrm{Na}^{+}$and an amino acid enter as co-substrates according to the usual kinetic formulations (Y. INUI AND H. N. CHRISTENSEN, unpublished results).

The present results suggest that a single sodium ion, rather than two, frequently enters a rate-limiting event in amino acid transport.

This work was supported in part by a grant (HD-or 233) from the Institute of Child Health and Development, National Institutes of Health, U.S. Public Health Service, and a grant from the Jane Coffins Child Memorial Fund for Medical Research, K.P.W. being a Fellow of this Fund during this work. He also received a Wellcome Research Travel Grant. E.E. and P.F.H. are U.S. Public Health Service trainees, the former under the Communicable Diseases Center, Atlanta, Ga., U.S.A.

Department of Biological Chemistry,

K. P. WHEELER

The University of Michigan,

Y. INUI

Ann Arbor, Mich. (U.S.A.)

P. F. HollenberG

E. EAvENSON

H. N. Christensen

I H. N. Christensen and T. R. Riggs, J. Biol. Chem., I94 (I952) 57.

2 T. R. Riggs, L. M. Walker and H. N. Christensen, J. Biol. Chem., 233 (1958) I479.

3 H. Kromphardt, H. Grobecker, K. Ring and E. Heinz, Biochim. Biophys. Acta, 74 (I963) 549.

4 G. A. VIDAVER, Biochemistry, 3 (I964) 795.

5 G. A. VIDAVER, Biochemistry, 3 (I964) 662.

6 R. K. Crane, G. Forstner and H. Eichrolz, Biochim. Biophys. Acta, in the press.

Received July I2th, I965

Biochim. Biophys. Acta, Io9 (I965) 620-622

PN 4 I 035

\section{Photoassimilation of organic compounds by autotrophic blue-green algae}

A number of photosynthetic microorganisms including eucaryotic algae, bluegreen algae and photosynthetic bacteria appear to be strict photoautotrophs, i.e., they grow only in the light with carbon dioxide as sole source of cell carbon. The reason for the inability of such strict photoautotrophs to grow on organic compounds is not clear. Studies on the strictly photoautotrophic green sulphur bacteria of the genus Chlorobium have established that these organisms can assimilate certain organic compounds into cell constituents ${ }^{1,2}$. Since many blue-green algae are reported to be unable to grow heterotrophically in the dark, it was of interest to determine whether such strictly photosynthetic blue-green algae are able to assimilate simple organic compounds in the light. It has been found that Anacystis nidulans is able to assimilate acetate in a light-dependent process, and that acetate is incorporated into a limited 